Article

\title{
Complex Customer Loyalty Measurement at Closed-Loop Quality Management in B2B Area-Czech Example
}

\author{
Jaroslav Nenadál *(D), David Vykydal and Eva Tylečková
}

\author{
Department of Quality Management, Faculty of Materials Science and Technology, VSB-Technical University of \\ Ostrava, 17. Listopadu 2172/15, 70800 Ostrava-Poruba, Czech Republic; David.vykydal@vsb.cz (D.V.); \\ eva.tyleckova.st@vsb.cz (E.T.) \\ * Correspondence: jaroslav.nenadal@vsb.cz
}

check for updates

Citation: Nenadál, J.; Vykydal, D.; Tylečková, E. Complex Customer Loyalty Measurement at Closed-Loop Quality Management in B2B Area-Czech Example. Sustainability 2021, 13, 2957. https://doi.org/ $10.3390 /$ su13052957

Academic Editor: Martí Casadesús

Received: 21 January 2021

Accepted: 3 March 2021

Published: 9 March 2021

Publisher's Note: MDPI stays neutral with regard to jurisdictional claims in published maps and institutional affiliations.

Copyright: (C) 2021 by the authors Licensee MDPI, Basel, Switzerland. This article is an open access article distributed under the terms and conditions of the Creative Commons Attribution (CC BY) license (https:/ / creativecommons.org/licenses/by/ $4.0 /)$.

\begin{abstract}
The main objective of this article is to present our proposal of complex customer loyalty measurement within external feedback loops as a response of Industry 4.0 concept in the area of advanced quality management for business-to-business (B2B) relationships, as customer loyalty and organisational sustainability are two critical factors for long-term success. To reach the goal, deep literature analysis, special field research, interviews with specialists, and development of a new model of closed-loop quality management systems, which are created for Quality 4.0 environment, were used. A new term, complex customer loyalty, is introduced, and twelve basic steps of its measurement are briefly explained, including a set of loyalty indicators, all regarding specific characteristics of B2B context. Special research confirmed that only about $15 \%$ of Czech organisations use some systematic approach to customer loyalty measurement within B2B area. In the majority of Czech B2B organisations, closed-loop quality management systems are mostly in early phases of their development. However, there is no doubt that complex customer loyalty measurement will be an important part of these systems. The proposals presented in this article are mostly universal and should be applied not only to Czech companies.
\end{abstract}

Keywords: customer loyalty; customer loyalty measurement; Quality 4.0; quality management system; closed-loop quality management; sustainability

\section{Introduction}

Industry 4.0, launched a few years ago by countries such as Germany and the USA, has discovered a great opportunity for further quality management development. Based on Industry 4.0, the term Quality 4.0 was established, under which all aspects and issues of quality management in the digital era are addressed. The most valuable studies in the area of Quality 4.0 are probably done under LNS Research Company. Their research indicates that most of industrial companies will have to be transformed to Industry 4.0 during the next five years, including quality management conversion [1]. A Deloitte group [2] has explored ways in which manufacturers can use technologies of Industry 4.0 to transform customer relationships: Industry 4.0 technologies enable manufacturers to engage with their customers and meet customers' ever-changing preferences through quick feedback. Kupper et al. [3] carried out a special study focused on the opportunities and challenges arising from Quality 4.0. It shows that only a few companies have made substantial progress towards adopting Quality 4.0 concept. A. Chiarini [4] found a lack of information on how to support customer value creation in the framework of Industry 4.0 concept establishing. Quality 4.0 represents a remarkable challenge for all types of organisations, as it helps to disrupt obviously stiffed, rigid, and formal approaches to quality management based, for example, on ISO 9000 series of standards. All areas of quality management processes (planning, control, assurance, and improvement) can be efficiently developed by a suitable combination of traditional quality management methods and tools and also using new technologies such as Cloud Computing, Big Data, Machine 
Learning, Internet of Things, etc. Quality 4.0 is thus moving upwards to become a strategic priority for many manufacturing companies. J. S. Lim [5] identified three key topics for the practical application of Quality 4.0 in manufacturing organisations:

- Real time quality management,

- Quality Big Data,

- Computer-aided management.

Zonnenshain and Kenett [6] consider quality management as a data-driven discipline. J. Antony [7] argues that Quality 4.0 can be utilised for understanding the type of customers for today and tomorrow and their expectations through Big Data analytics and Voice of Customer analysis.

These and some other opinions create a suitable background for further research and development. This article only opens one of the possibilities: it proposes the possible direction of complex customer loyalty measurement within external feedback loops in the area of advanced quality management, with respect to fundamental features of Industry 4.0 and Czech industrial companies.

In most of the Czech organisations, the Quality 4.0 concept is still of its early stages in adaptation, even though the awareness about it is relatively high. There are many uncertainties related to possible approaches to Quality 4.0 practical implementation. Socalled closed-loop quality management systems should be a suitable basis for practical establishing and development of Quality 4.0, especially in the business-to-business (B2B) area. Very complex supply chains can occur in this area. Zimon et al. [8] discovered an interesting research gap when exploring the current state of management systems: poor quality of mutual communication between suppliers and consumers, among others, in the area of consumer feedback.

The closed-loop quality management systems should be designed as a natural part of the organisation's overall management system based on advanced quality management principles, which enable them to link all quality management processes and performance data in an efficient and effective manner. The basic structure of such systems as a useful combination of external, internal, horizontal, and vertical feedback loops is presented later. Customer loyalty measurement should be considered a key element of these feedback loops. The system approach to customer loyalty measurement was established nearly 25 years ago. However, the majority of approaches to such measurement, as well as loyalty indicators, have been developed and adapted for the commercial area regarding end customers (B2C, Business to Customers.). B2B area is a little underestimated, yet findings in Section 3.2 will show more detailed information.

\section{Materials and Methods}

The main objective of this article is to present a proposal of a complex customer loyalty measurement within external feedback loops as a response to Industry 4.0 concept in the field of advanced quality management for B2B relationships. The methods and approaches shown in Figure 1 were used to achieve the respective results.

Deep literature analysis in the areas of interest was performed, first of all, in order to identify the current state in the area of closed-loop quality management systems, customer loyalty, and links to sustainability. The main findings of the analysis of the literary resources are presented in Sections 3.1 and 3.2. These findings have become a proper basis for further research and development activities. In terms of development activities, they focused on designing a complex customer loyalty model together with a special methodology of complex customer loyalty measurement tailored to Czech B2B area. The results are presented in Sections 4.1 and 4.3. Relevant research focused on, among other things, investigations concerning managerial views related to the necessity of traditional quality management conversion towards Quality 4.0 concept. In this case, semistructured interviews with representatives of 23 Czech production companies were used in combination with a focus group technique. This event was a part of a special seminar organized by VSB-Technical University in November 2019. The findings are presented in Section 6, especially in the 
Table. A special field research was conducted, the aim of which was to find out how the complex customer loyalty measurement within B2B area is practically developed and used by Czech production organisations. Section 4.2 provides detailed information on the survey features and its main findings. To identify the main and universal lessons learned, a certain qualitative and quantitative data processing and synthesis of the information obtained were used. All results are summarized in Sections 5 and 6, including some issues of further research.

\section{Literature review}

Aim: to identify state of art in areas of the closed-loop quality managementsystems, customerioyalty measurement and sustainability

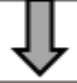

2. Analysis of findings from the literature review

Aim: to define basis for the next research activities

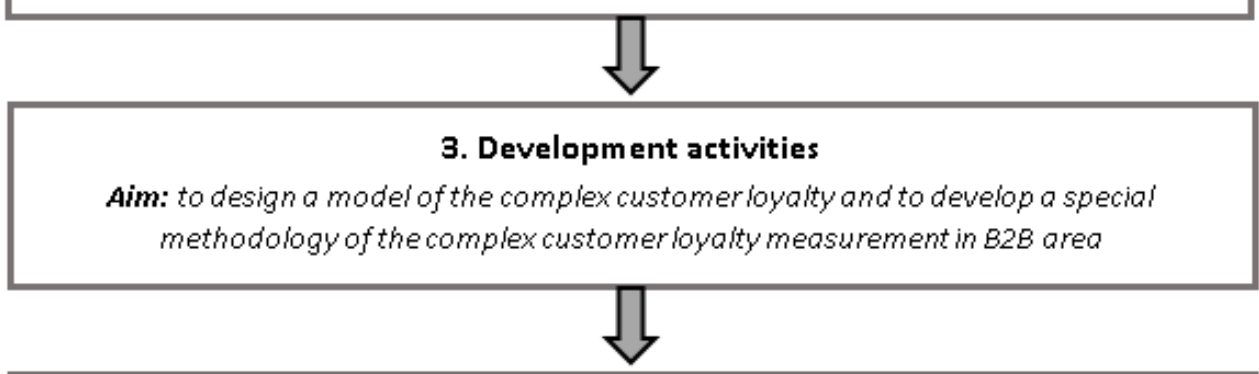

\section{Investigation of managerial opinions}

Aim: to discover real opinions of some Czech managers related to necessity of traditional quality management conversion towards Quality 4.0 concept

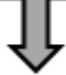

\section{Field research}

Aim: to identify how approaches to the complex customerloyaity measurement are practicalily used by czech production companies

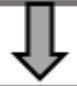

\section{Identification of lessons learned}

Aim: to formulate the most important and valid conciusions and challenges for the next research

Figure 1. Logical activities of the conducted research (own work).

\section{Theory and Background}

This section will provide an overview of the necessary literature. As the main topics (closed-loop quality management and customer loyalty measurement) are usually discussed separately in relevant references, this review is also divided into two subsections.

\subsection{Literature Review Related to the Closed-Loop Quality Management}

Key milestones of previous quality evolution, from quality inspection to organisational excellence, were described many times [9-11]. However, the prospects for the future of quality management are not quite clear. Let us make a brief preview of some relevant 
opinions. Radziwill [12] considers the future of quality management as a revolutionary matter. R.G. McGrath [13] perceives future organisations as vehicles for creating complete and meaningful experiences, based on comprehensive customer voicing. Sundaram [14] presented the results of representative research in manufacturing companies, which was published by Frost \& Sullivan: "Industrial producers will do well to probe into innovative technologies and tools that can help integrate customer operations into their systems and, concurrently, help improve process efficiencies, bring down production costs and boost factory performance. To achieve this, manufacturing organisations are making strategic investments in quality management solutions." In addition, the belief of organisations that traditional quality management systems are increasingly making a move towards a more future-ready and closed-loop approach is expressed there. Most of the current trends of quality management should be adapted to Industry 4.0 environment. For example, Cattaneo et al. [15] describe how lean thinking should be implemented in the context of a smart factory, and the findings confirm that quality management principles and approaches have a strong potential for supporting a company's digitalisation initiative [16].

The term "closed-loop quality management" is discussed in special journal articles as well as in the online environment. However, there is no consensus, which can be taken as clear proof that this field is under progress. The following references provide evidence of it. Littlefield [17] explains how to understand this term: "Closed-loop quality management essentially means connecting quality process or performance data from one area to another, always with the goal of improving quality earlier." He also describes two main areas of such an approach: manufacturing and suppliers. The role of closed-loop quality management at manufacturing processes was explored by special LNS research activities [18], where impacts to the value chain, statistical process control, risk management, complaint handling, and other activities were investigated. The closed-loop approach should be looked upon also as a chance for supplier's development [19]. Nikolaidis [20] emphasizes an important improvement of mutual communication and data exchange between consumers and suppliers. The application of the closed-loop principle in the relationship between consumer and supplier, the so-called "closed-loop supply management," is described by Almaraj and Trafalis [21] and many other authors.

Goulévitch [22] provides eight examples of how closed-loop quality management systems should work, including transparency in production processes, traceability, integration with ERP systems, facilitation of lean processes, etc. However, the most convincing facts about the necessity to design and develop closed-loop quality management were brought by special investigations performed by members of Aberdeen Group and published by Littlefield and Shah [23]: A lot of data on how to shift from laggard or industry average performance to the best-in-class through feedback loops are conclusively presented there. M. Sony et al. [24] distinguish three forms of integration within closed-loop quality management in the Quality 4.0 era:

- horizontal (which is along the entire value creation chain),

- vertical (which is alongside the organisation's system),

- $\quad$ end-to-end (along the product life cycle).

Foidl and Felderer [25] see horizontal, vertical, and end-to-end forms of integration as important topics for the further research.

On the basis of this brief literature review, it is possible to generalize some provisional conclusions in the area of closed-loop quality management:

(a) The closed-loop quality management is considered as a "must have" future approach to quality management development in all organisations.

(b) There is no available exact terminology related to closed-loop quality management area as a result of expert consensus.

(c) The most frequent investigations and practical implementations of closed-loop approach cover internal production processes, with the aim to improve processes capability. 
(d) There is only a limited set of data focused on the cost-benefit analysis of closed-loop quality management initiatives at present.

(e) The closed-loop quality management does not reject traditional and proven quality management methods and tools. On the contrary, it enriches them with the advantages and possibilities of the digital era.

(f) Development of closed-loop quality management systems is under progress all over the world.

(g) Information about external loops based on customer loyalty measurement, monitoring, and communication as a part of closed-loop quality management is completely lacking.

In particular, insufficient establishing of the closed-loop quality management systems as a combination of internal, external, horizontal, and vertical loops (taking into consideration feedback loops from customers) represents a research gap as well as an opportunity for further research.

\subsection{Literature Review Related to Customer Loyalty Measurement (with Respect to Sustainability)}

Recent research conducted by Sisodia and Forero [26] on how to transition into Quality 4.0 has proposed (among other things) a road map for this transition. Special phases of this road map emphasize all stakeholders' involvement, including customers.

First of all, a core term, "customer loyalty," should be explained. Hayes [27] defined this term as follows: "customer loyalty is a twofold customer behaviour resulting in an effective continuation and development of a business relationship in the one hand and in the recommendation of the supplier, its brand, products or services to any potential customer on the other hand." Watson [28] says that customer loyalty is a collection of attitudes aligned with a series of purchase behaviours that systematically favour one entity over competing entities. However, customer loyalty is more than just behaviour or repeated business. It also represents a positive level of customer commitment to suppliers. Many authors have started their serious discussions about customer loyalty (including relationships between customer satisfaction and customer loyalty) in the 1990s, when clear evidence appeared, saying that, in spite of the high level of customer satisfaction, a lot of organisations suffered a serious market loss [29-35]. The first remarks related to customer loyalty have been already published in Czech Republic in 2001 [36]. In addition, a clear link between efficient quality management and customer loyalty was confirmed [37]. Some authors discuss the influence of various factors on customer loyalty, including the relationship between customer satisfaction and loyalty; [38-41] represent good examples. The indisputable relationship between customer loyalty and overall supplier performance was investigated and confirmed by Reinartz \& Kumar [42].

Most of customer loyalty studies have focused on services, which are typical for B2C areas [43-46]. Only a limited number of papers are dedicated to customer behaviour in B2B area, where customers are not individuals but other units within the whole supply chain, usually purchasing companies. Except for the article of Rauyruen \& Miller [37], let us mention Bardauskaite [47], first of all, who analysed very closely some papers and articles and identified the main loyalty determinants in B2B service context. Some findings related to power of The European Customer Satisfaction Index (ECSI) model were presented by Askariazad \& Babakhani [48]. An interesting study published by Russo et al. [49], where different configurations of costs, returns management, customer value, and customer satisfaction were analysed in order to approve a close relation to the customer's future behaviour, is also impressive. A multidimensional construct, the customer engagement with three dimensions, cognitive, emotional, and behavioural, was described as a prerequisite for customer loyalty in B2B area by Youssef's team [50]. Unfortunately, standards such as ISO 9001:2015 [51] or ISO 9004:2018 [52] do not mention the term customer loyalty at all. This absence must be considered as a serious weakness of these documents. Therefore, a short quotation cited from [53], "Studying and understanding customer's loyalty is crucial 
in today's dynamic world due to changing technology, contexts, and lifestyles," can serve as a convenient umbrella statement at this moment.

When discussing some quality management or customer loyalty issues, impact on and relationships to sustainability must not be ignored. Quality management principles and product development activities can make sustainability more actionable [54]. Nguyen, Phan, and Matsui [55] established four quality management processes that have significant and positive impact on sustainability performance: top management support, design for quality, quality data reporting, and continuous improvement. Although their investigations were carried out in Vietnamese companies, experience has shown that these findings could be understood as universal. An important set of data must come from customer feedback. Veldwijk [56] declares that more than two-thirds of consumers consider sustainability when purchasing, and $47 \%$ of consumers would pay more for a sustainable product. Garai [57] presents four benefits of sustainability in loyalty programs: more in-store visits, larger community, reduced production, and greater social engagement. He supports them by examples from some companies. J. Weinberg [58] offers similar information and shows three factors that lead to the fact that sustainability is increasingly becoming a major consideration for a growing number of customers: the strengthening acceptance of climate change, a strong resolve to take action regarding sustainability from the youth segment of customers, and increased importance of the feelings associated with making sustainable choices. Some authors (Siva et al. [59], for example) argue that customer focus strongly supports approaches to sustainable development. Brunet and Llach [60] bring interesting findings related to the promotion of a sustainable economy through reducing the consumption of new products.

It seems to be clear that a feature usually called corporate sustainability ought to be focused with respect to future customer's behaviour-findings published by Strenitzerova and Gaňa [61] are evidence of relationship between them.

Corporate sustainability is an important part of the overall sustainability area. According to the Dow Jones Sustainability Index [62], corporate sustainability is a business approach that creates long-term shareholder value by embracing opportunities and managing risks deriving from economic, environment, and social development. Considering this definition, corporate sustainability can be seen as interwoven with the concept of corporate social responsibility: this concept was based on the idea of sustainability, and it recommends what different organisations should do to reach a high level of sustainable development. The definition of corporate social responsibility from ISO 26000 standard [63] is quite conclusive: "The responsibility of an organisation for the impacts of its decisions and activities on society and the environment, resulting in ethical behaviour and transparency which contributes to sustainable development, including the health and well-being of society; taken into account the expectations of stakeholders; complies with current laws and is consistent with international standards of behaviour; and is integrated throughout the organisation and implemented in its relations." A set of facts that significantly confirm the strong and positive link between corporate social responsibility and customer loyalty, regardless the branch and business, was brought by [64-67].

On the basis of this review, the following general conclusions should be identified in the area of customer loyalty measurement (with respect to sustainability):

(a) Customer satisfaction measurement (required by ISO 9001:2015 or IATF 16949:2016 standards) is currently not sufficient.

(b) Unlike customer satisfaction, which only provides past view, customer loyalty offers a glimpse into the future.

(c) All fundamental loyalty determinants and factors have been already identified by many authors and loyalty models.

(d) The majority of such models, including indicators, are usually tailored for commercial services in advance. 
(e) Only a limited number of investigations focused on approaches and methodologies of customer loyalty measurement in B2B manufacturing context, including automotive industry.

(f) Perceptions of social, environmental, and economic issues of sustainability influence future customer behaviour and their level of loyalty.

(g) Socially responsible consumers will be loyal only if the suppliers are able to meet requirements regarding to sustainable products and service.

(h) Customer loyalty measurement and monitoring should be an important part of strategic management in all types of organisations.

(i) In B2B area, approaches and methods of customer loyalty measurement that very often operate within complex supply chains must respect all specific features of mutual relationship between suppliers and consumers.

(j) Closed-loop quality management systems will serve as an effective basis for such measurement.

How to integrate customer loyalty measurement into closed-loop quality management systems based on combinations of internal, external, horizontal, and vertical loops represents another research gap. This statement complies with the suggestions of Sader et al. [68], who argue that direct communication of customers' expectations and perceptions is one of the serious topics of further research. Additionally, Goecks et al. [69] confirm, on the basis of literature review, that all decision-makings within quality management systems must be supported by objective input data. They see this fact as another research gap.

The proposed framework and indicators (which is described in the following section) will try to take all these issues into consideration.

\section{Results}

Now, on the basis of some provisional conclusions (presented in the previous section), the most important results of our investigation and developing activities can be presented. They should be seen as a small contribution to the overall effort in the areas of research gaps identified above.

\subsection{Framework of Closed-Loop Quality Management System}

First of all, it is necessary to present how closed-loop quality management systems should be seen. It is a part of the overall organisation's management system based on advanced quality management principles, which enables the linking of all quality management processes and performance data to improve the organisational quality. The term "organisational quality" was originally launched by ISO 9004 standard [52]: "Organisational quality refers to the inherent characteristics of the organisation which enhance its ability to achieve sustained success."

With respect to [24,25], closed-loop quality management systems (CLQMS) should be designed and developed as a suitable and complex mixture of internal, external, horizontal, and vertical loops. Its basic framework is drawn in Figure 2. These loops must naturally cover all organisational levels, from strategic to shop floor, and must be adapted to specific organisational environment and various types of processes. The most important features of these loops are briefly described in Table 1 . The complex customer loyalty monitoring and measurement should be integrated as a key external loop. Results or findings from this measurement must be communicated in advance through relevant vertical loops directed to the organisation's top management team. 


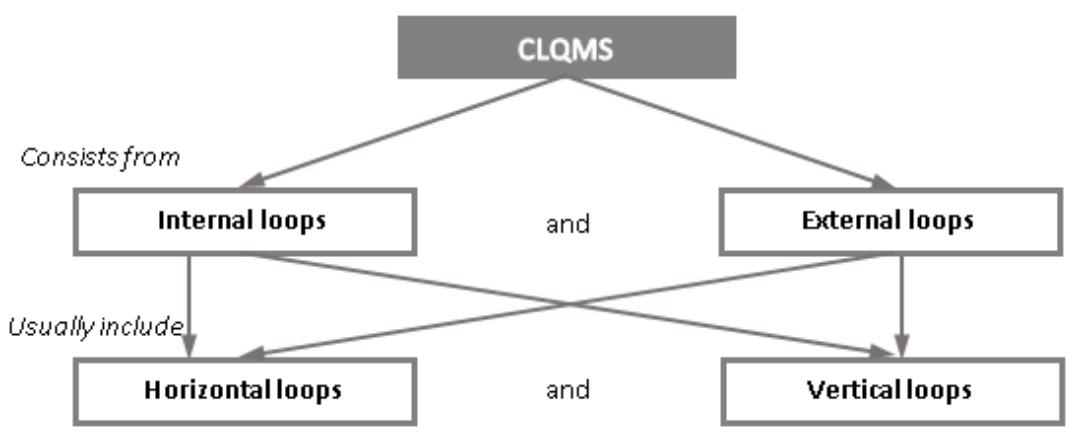

Figure 2. Basic framework of closed-loop quality management system (own work).

Table 1. Important features of different loops at closed-loop quality management systems (CLQMS) (own work).

\begin{tabular}{|c|c|}
\hline Loops & Loops Features \\
\hline \multirow{3}{*}{ Internal loops } & Cover the internal organisation's processes and performance indicators \\
\hline & Are based on feedback from owners of internal processes \\
\hline & Are focused on processes capability \\
\hline \multirow{3}{*}{ External loops } & Cover external processes and performance indicators \\
\hline & $\begin{array}{l}\text { Are based on feedback from external stakeholders, } \\
\text { especially customers }\end{array}$ \\
\hline & Are focused on the external stakeholder's perception \\
\hline \multirow{3}{*}{ Horizontal loops } & Are located within single organisational level \\
\hline & Describe how individual processes are under control \\
\hline & Mutual interaction among them is expected \\
\hline \multirow{3}{*}{ Vertical loops } & Are located and adhere at least two different organisational levels \\
\hline & Describe how loops of lower levels are under control \\
\hline & Enable organisation's strategy and policies deployment and review \\
\hline
\end{tabular}

As for customer loyalty, B. Hayes's definition, which was presented in Section 3.2, is accepted. Considering the specific environment of $\mathrm{B} 2 \mathrm{~B}$ area, a generic complex customer loyalty model is proposed, according to the scheme from Figure 3. This model (which could be applied also in B2C area) is a combination of two loyalty dimensions and three loyalty types. Emotional, as well as behavioural loyalty dimension is affected by the consumer's perception of suppliers' performance in the area of sustainability. In truth, it respects only one of the possible approaches to customer loyalty measurement, through future customers' intentions, as it should be crucial for objective strategic decision making. Other possible approaches to customer loyalty measurement, through loyalty effects, customer loss, or loyalty index are omitted, considering the fact that, for B2B areas, they are not fully fitting. Table 2 describes the three loyalty types identified already by B. Hayes [33,43] regarding the future consumers ' behaviour. 


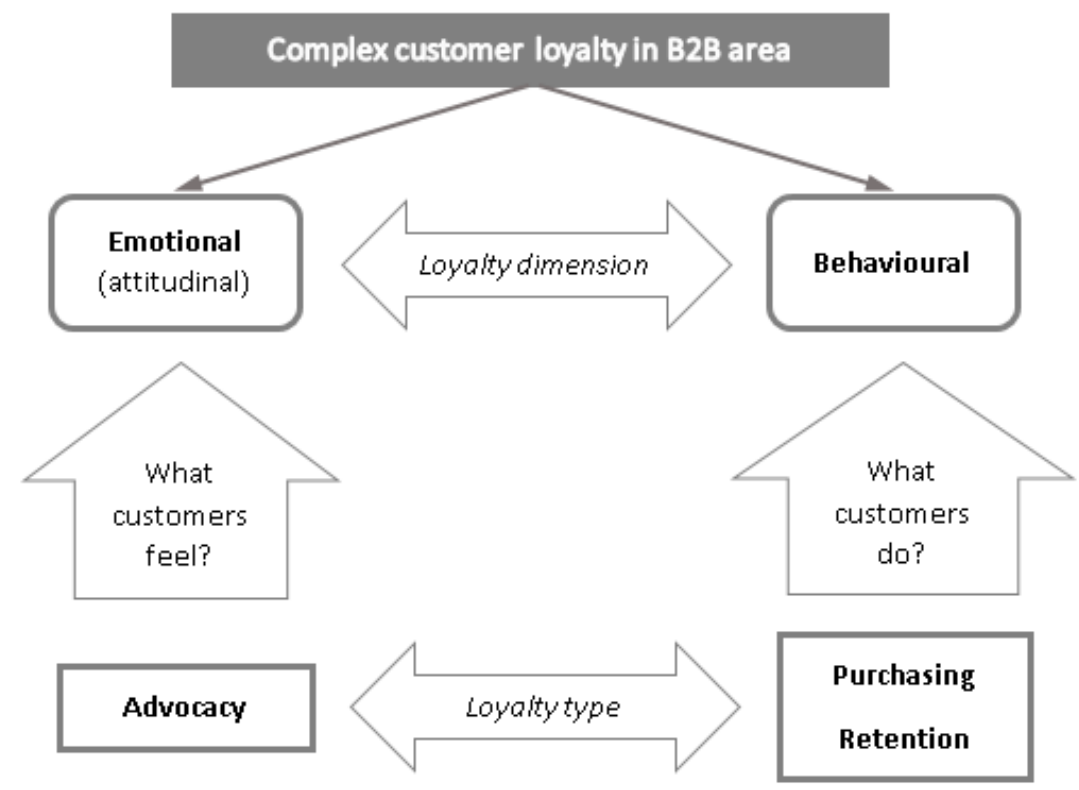

Figure 3. Generic model of customer loyalty in business-to-business (B2B) area (own work).

Table 2. Description of customer loyalty types for B2B area (adapted according to B. Hayes [33,43]).

\begin{tabular}{cc}
\hline Customer Loyalty Type & Short Description \\
\hline Advocacy & $\begin{array}{r}\text { It reflects the degree to which industrial customers (consumers) } \\
\text { will be advocates of the supplier's organisation and can be used } \\
\text { to increase the size of the consumer's base. }\end{array}$ \\
Purchasing & $\begin{array}{r}\text { It reflects the degree to which industrial customers (consumers) } \\
\text { will increase their purchasing behaviour and can be used to } \\
\text { increase the number of purchases by industrial } \\
\text { customers (consumers). }\end{array}$ \\
Retention & $\begin{array}{c}\text { It reflects the degree to which industrial customers (consumers) } \\
\text { will remain with a given supplier's organisations and can be } \\
\text { used to increase the average industrial customer life. }\end{array}$ \\
\hline
\end{tabular}

In practice, organisations can use a wide range of loyalty indicators, but not all of them are relevant to B2B area. Therefore, regarding this area, the following set of indicators for each of the loyalty dimension and type is shown by Table 3. Proposed indicators were designed on the basis of lessons learned from the behaviour and decision-making of industrial consumers purchasing certain technical equipment, machinery, transport means, etc. They, in the best way, describe the alternatives of future industrial consumers' behaviour. Naturally, such a set of indicators is not comprehensive; it should be used only as a base image. Suppliers may design some other relevant indicators, such as market share, etc. On the other hand, they may not use all presented indicators in case of practical feedback. Selection of core indicators strongly depends on the types of products supplied, frequency of sales, objectives of loyalty programs, etc. Naturally, these indicators can also be used to examine the ability of suppliers to meet relevant sustainable requirements.

Nevertheless, a suitable formula for each of the selected indicators must be defined. The two following formulas may serve as examples.

Likelihood to purchase different products, $P_{p d p}$ could be calculated by formula:

$$
P_{p d p}=N_{p d p} / n
$$


where $N_{p d p}$ is the number of consumers who stated that they also buy different products without any hesitation; $n$-is the sample size (total number of consumers who participated in a special market research).

Table 3. Proposed set of loyalty indicators for B2B area (own work).

\begin{tabular}{|c|c|}
\hline Customer Loyalty Type & Possible Loyalty Indicator \\
\hline \multirow{4}{*}{ Advocacy } & Customer acquisition rate \\
\hline & Likelihood to choose again \\
\hline & Likelihood to recommend \\
\hline & Level of trust \\
\hline \multirow{7}{*}{ Purchasing } & Likelihood to continue purchasing the same products \\
\hline & Likelihood to purchase different products \\
\hline & Likelihood to purchase more expensive products \\
\hline & Likelihood to increase frequency of purchasing \\
\hline & Upselling ratio \\
\hline & Sales increasing due to loyal customers \\
\hline & Repeat purchase rate \\
\hline \multirow{9}{*}{ Retention } & Likelihood to stop purchasing \\
\hline & Likelihood to switch to another provider \\
\hline & Customer lifetime value \\
\hline & Retention rate \\
\hline & Customer churn rate \\
\hline & Revenue retention \\
\hline & Service contract renewal rate \\
\hline & Customer attrition rate \\
\hline & Participation rate \\
\hline
\end{tabular}

On purpose of the retention rate, $R R$ calculation should be valid:

$$
R R=[(C E-C A) / C S] \times 100[\%]
$$

where $C E$ denotes the number of consumers at the end of the period of interest, $C A$ denotes the number of consumers acquired during this period, and CS denotes the number of consumers at the start of the period investigated.

\subsection{Current State of Complex Customer Loyalty Measurement in Czech Production Companies}

A research team from Department of Quality Management at VSB-Technical University of Ostrava carried out an empirical field research in Czech production organisations in the period of time from November 2018 through January 2019. The main goal of this research was to investigate how complex customer loyalty measurement within B2B area is practically developed and used by Czech production organisations.

Two basic hypotheses were declared:

Hypothesis 1 (H1). Complex customer loyalty measurement is rarely understood and applied in Czech production organisations.

Hypothesis 2 (H2). Over the course of time, the state of complex customer loyalty measurement made no progress in Czech production organisations. 
In total, 230 Czech production organisations from various areas of business were randomly selected. Data gathering was based on a structured questionnaire, which could be completed mostly electronically. Additionally, interviews with some quality professionals were also conducted. The response rate was $28 \%$, which means that 65 organisations provided relevant data for the further processing. However, 65 respondents cannot be seen as fully representative sample. The prevailing reluctance to share opinions reflects the lukewarm approach of Czech industrial companies to any serious monitoring and measurement related to customer feedback. Figure 4 shows the distribution of the organisations in terms of their business areas.

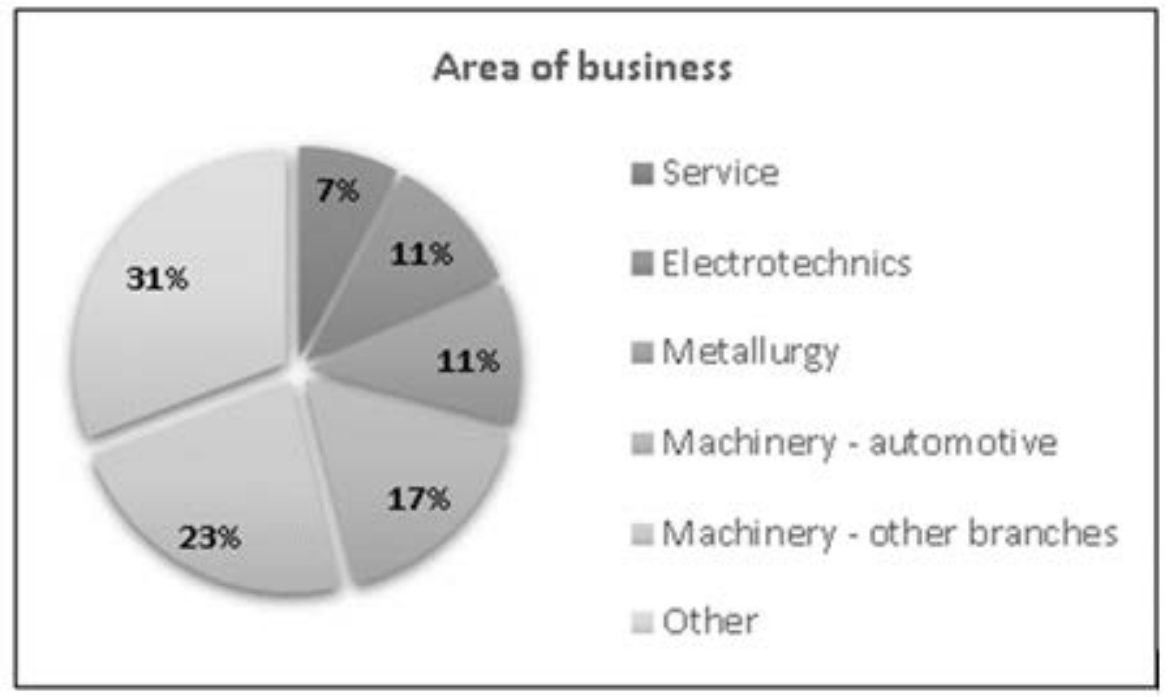

Figure 4. Distribution of organisations from the business area point of view (own work).

The key finding is this: only 10 in 65 (it means about 15\%) Czech production organisations have already implemented and use a systematic approach to customer loyalty measurement, mostly to contribute to the customer orientation principle. An important majority of Czech production companies ignore this feedback. The reasons for this ignorance are given in Table 4 . All the answers offer clear evidence of a deep misunderstanding of the basic purpose and aim of such feedback.

Table 4. Customer loyalty measurement in Czech production organisations: Why not? (own work).

\begin{tabular}{cc}
\hline Reason & Frequency of Response \\
Unknown & 14 \\
It is not required & 7 \\
Owners or managers do not require it & 5 \\
Our customers do not require it & 4 \\
Top management is not interested in such measurement & 4 \\
There is no need to investigate this feedback & 4 \\
Such a measurement is provided by distributors & 3 \\
Contracts are obtained on the basis of competitive tendering & 3 \\
Monopoly status & 2 \\
It is not required by international standards & 2 \\
Our company is not supplier for end customers & 2 \\
Complex loyalty measurement is not key for our business & 2 \\
Loyalty follows from regular customers' evaluations & 1 \\
Suitable methodology is not available & 1 \\
We provide only custom-made production & 1 \\
\hline
\end{tabular}

For the purpose of $\mathrm{H} 2$ hypothesis, a special comparison between the results of similar field research (which was made in 2012) [70] was realized, as well. Main data are sum- 
marized in Table 5. Findings discovered that, during this time, the state of the customer loyalty measurement got even worse in Czech production organisations that are active in B2B area.

Table 5. Comparison of field research findings from 2012 and 2018 (own work).

\begin{tabular}{ccc}
\hline Item & $\mathbf{2 0 1 2}$ & $\mathbf{2 0 1 8}$ \\
\hline Total number of organisations selected for the research & 183 & 230 \\
Total number of organisations with relevant response & 34 & 65 \\
Response rate & $18 \%$ & $28 \%$ \\
total number of organisations which perform customer loyalty measurement & 10 & 10 \\
Ratio of organisations which perform customer loyalty measurement to the & $29 \%$ & $15 \%$ \\
total number of organisations with relevant response & & \\
\hline
\end{tabular}

Only key results from the investigation are presented above to confirm both hypotheses. Complete results and findings were published in master thesis of Tylečková [71]. The key lesson learned said that most of Czech production companies are in bad need of suitable methodology for complex customer loyalty measurement as a part of closed-loop quality management system. The following Section 4.3 briefly describes the basic steps of such methodology.

\subsection{Methodology Framework of the Complex Customer Loyalty Measurement in B2B Area}

Figure 5 presents 12 basic steps of such methodology. To be clearly understood, each of them will be now very briefly described.

The first step is a typical leadership activity. It is obvious that the traditional quality management systems' (based on ISO 9001:2015 requirements, for example) conversion to closed-loop quality management systems is a strategic change. Therefore, it is necessary to reach a consensus among members of the organisation's top management team. The top managers should also

- $\quad$ assign relevant responsibilities and authorities related to all activities aimed at complex customer loyalty measurement and

- $\quad$ release all the necessary resources for such measurement, including people and money.

Given that most producers in B2B area share a relatively wide product portfolio, the selection of key products for the complex customer loyalty measurement may represent further task. Authority for these decisions should be also assigned to the organisation 's top management team. Here, the impact of product's sales on overall business performance ought to be used as a principal selection criterion there.

As for the determination of the measurement frequency, it strongly depends on the delivered products proprieties and functions. For example: key consumers of small machinery parts (which are produced in large volumes) should be asked for feedback every year. On the contrary, the behaviour or future intentions of consumers buying complex machines, transport vehicles, etc. should be investigated by the producer for a longer period of time, depending on their frequency of delivery.

Four basic approaches to customer loyalty measurement were mentioned above: through future customers' intentions, loyalty effects, customer loss, and loyalty index. The first of them, exploration of future customers' intentions, should play a decisive role in B2B area. 


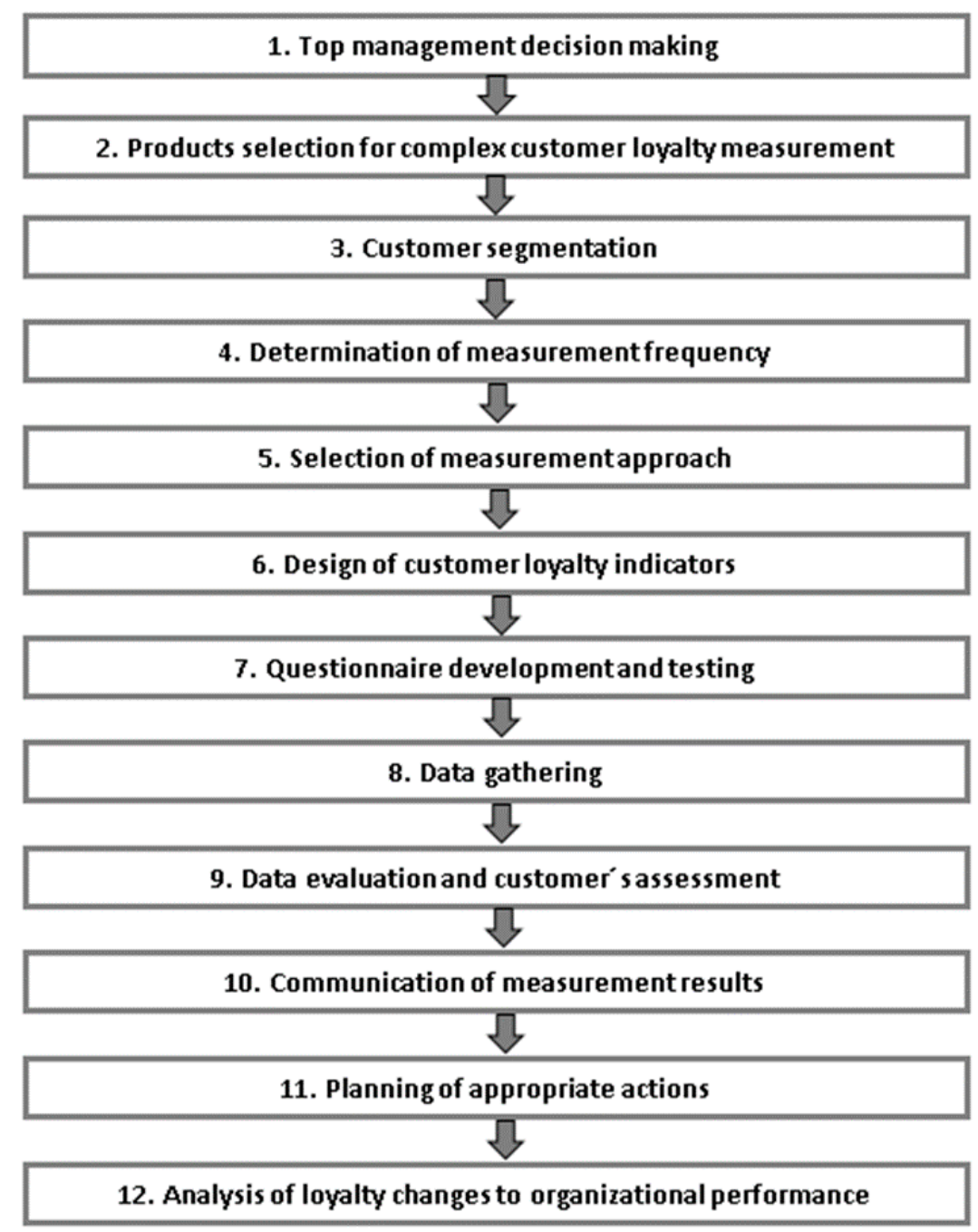

Figure 5. Basic steps of complex customer loyalty measurement in B2B area (own work).

When thinking about a set of loyalty indicators, Table 3 could serve as a helpful guideline. It is not necessary to use all of them. Any supplier should choose the indicators that will most effectively demonstrate customer loyalty. However, all the loyalty types (advocacy, purchasing, as well as retention) should be included. To identify the necessary input data, mathematic formulas (similar to Equations (1) or (2), for example) must be designed for each proposed loyalty indicators.

The designed set of loyalty indicators serves as important input information for people who create and test the questionnaire. Questionnaires must be considered a fundamental tool for any objective data gathering from consumers selected for any survey. For the purpose of complex customer loyalty in B2B area, the Likert-type format is recommended due to simplicity, utility, and relatively high level of objectivity.

Two key issues need to be addressed when discussing data gathering:

- Customer sampling and

- Data collection methods.

Activities commonly referred to as customer sampling should be taken into consideration in the case it is not possible to carry out the survey to all intended consumers. Such a situation can only be sporadic in B2B area, but it cannot be excluded. If the customer sampling is in-store, the organisations may use judgmental or statistical sampling.

Due to data collection regarding the extensive development of information media, closed-loop quality management systems, including feedback from customers, will use of web-based customer surveys. In general experience, certain fears for low response rate do 
not occur in B2B areas: consumers are not anonymous, and feedback may be covered by a relevant formal agreement.

When all the survey data sets are available, they need to be evaluated in an appropriate way in order to assess customers in terms of their future behaviour and intentions. Documented procedure for such evaluation and assessment is expected within closed-loop quality management systems. Relevant statistical methods should be welcomed there, including time series, factor analysis, loyalty driver analysis, etc. All outputs from data processing should be recorded.

Customer's feedback data, related to their future intentions, can be viewed and communicated in a variety of ways. Management review process, also required by ISO 9001:2015 standard [51], seems to be the best platform. The set of input data should include complete complex loyalty indicators regarding to each of the key consumers, tracking its loyalty over time through trend charts, root cause analysis of loyalty changes, and proposals how to achieve a higher level of loyalty types in the next period. These proposals must be approved, released, and supported by top managers.

Top managers' decision-making are obligatory impulses for improvement and innovation actions. These actions are usually provided on the basis of standard improvement cycle [72] in order to achieve more positive customers' perceptions, experience, and retention. Each of such action is unique as feedback from customers usually contain various incentives for products innovations and customers' processes improvement.

The final step of complex customer loyalty measurement in B2B area is analysis of loyalty changes related to the organisation's performance. Unfortunately, there is currently no evidence about such an analysis in Czech organisations. However, it is clear that increasing customer loyalty through recommendations, repeated purchasing, increasing volume of purchased products, and the ability to not lose existing consumers is an essential prerequisite for economic surveillance in a competitive environment $[33,35]$. Research of the strong correlation between trends of loyalty indicators and financial growth should be required by the top managers of any supplier. However, there are two serious limitations: such an analysis requires large amount of input data and deep knowledge in the field of statistical data processing. The twelve steps above do not represent some revolutionary concept; they ought to help Czech Companies to start serious activities in the area of customers loyalty measurement.

\section{Discussion}

The Quality 4.0 concept shifts traditional quality management into the area of digitalization with comprehensive support of information technologies. In order to achieve a long-term economic success, the transformation of the current quality management systems towards closed-loop quality management systems seems to be an unquestionable necessity for all types of organisations. Such transformation is also newly underlined by the EFQM Model [73] and has been primarily analysed [74]. Criterion 3, engaging stakeholders, contains a special criterion, part 3.1-customers: build sustainable developmentand criterion 6, stakeholder's perception, asks for customer perception results obtained with the support of digital feedback. The main results presented in the previous section should be assessed from this perspective. They also comply with the statements declared by $[24,68,69]$.

A completely new definition of closed-loop quality management system has been proposed (Section 4.1), and it should be the basis for further specifications through academic and practical discussions. The basic framework of such systems as a suitable and comprehensive mixture of internal, external, horizontal, and vertical loops was also developed (see Figure 2 and Table 1). It reflects the challenge discovered in [25]. This framework is general-purpose, and it can be adapted by any organisation. Nevertheless, the data gathering and processing related to customer loyalty must be an indispensable part of any closed-loop quality management system. There is no doubt that Big Data analysis will have to be used here as consumers' perception should only be identified from a large 
set of data also gathered from various social media, etc. Customer loyalty measurement provides relevant view of the future purchaser's behaviour, which is crucial information for strategic management of any supplier's organisation; mere customer satisfaction data only offer back sight. That is why we have launched a new term, "complex customer loyalty," through Figure 3, with respect to the three loyalty types described by B. Hayes above $[33,43]$. The proposed set of lagging loyalty indicators included in Table 3 could serve as a valuable offer for all suppliers in B2B area. Moreover, it could also be used as a base for various market research. The 12 steps of complex customer loyalty measurement in B2B area (illustrated by Figure 5) should form a suitable framework for any serious investigation within external loops, even though it was primarily designed with respect to the current Czech situation in this area. However, each supplier is naturally expected to make this methodology more precise, according to its product (or service) portfolio and consumer segmentation. All advanced quality management systems should also include in their feedback loops information from other stakeholders (owners, employees, suppliers, etc.), and the methodology presented in Section 4.3 could be easily adapted there.

The nature of all results is definitely universal, regardless of the type of product, size, or locality of the supplier. Nevertheless, the findings from the empirical field research, briefly presented in Section 4.2 , should be considered an important exception: they apply only in the Czech environment.

\section{Conclusions and Lessons Learned for the Future}

Some partial conclusions were formulated earlier in Sections 3 and 4 of this paper. Now, let us summarize the final remarks, the main findings, and lessons learned:

(a) Closed-loop quality management systems are in the early stages of their development by majority of Czech organisations, regardless the product type and size, in spite of the fact that Industry 4.0 issues are very frequently discussed.

(b) Socially responsible consumers will be loyal only to the condition that Czech suppliers are able to meet requirements for sustainable products and service sustainability. This issue ought to be considered whenever the consumer's loyalty is taken into account.

(c) Awareness of the necessity of customer loyalty measurement has been absolutely insufficient by Czech producers for a long time. Only about $15 \%$ of Czech organisations provide a systematic approach to examination of future customer's intentions.

(d) Practically all Czech organisations are lacking in a suitable and comprehensive methodology in the field of customer loyalty measurement.

(e) Obligatory competitive tendering process is commonly recognized by Czech consumers as an objective obstacle in the B2B area when discussing importance of complex customer loyalty measurement.

(f) Managers in Czech organisations have no access to objective information about impacts of customer loyalty on the overall financial performance of the organisation, and what is even worse, they usually do not require this information for decisionmaking.

These points should be seen as a serious warning that ought to be registered by all Czech production companies, including the automotive industry. The first insight discovered a current Czech situation in B2B area, and the question is if some lessons learned should be also impulses for organisations abroad. In any case, the proposed complex customer loyalty model and relevant loyalty indicators could be also applied in other countries in an effort to develop advanced approaches to customers' feedback within any quality management system.

Quality remains and will remain one of the key success factors in relation to longterm economic sustainability and organisational excellence $[5,9,75]$. On the other hand, Krubasik [76] argues that the effectiveness of standard quality management practices is decreasing. Positive managerial consideration and permanent support of quality management systems as crucial tool for quality assurance, control, and improvement (with respect 
to long-term sustainability) urgently require their profound changes and comprehensive transformation towards complex closed-loop systems.

When discussing all the issues related to the necessity of the quality management transformation into Quality 4.0 concept with representatives of Czech organisations, a strong competitive environment was declared as a main driving force. As for closed-loop quality management systems, some advantages and barriers regarding their practical implementation were preliminary identified during these discussions and are presented in Table 6.

Table 6. The main advantages and barriers in area of the closed-loop quality management systems implementation at Czech organisations (own work).

\begin{tabular}{|c|c|}
\hline Advantages & Barriers \\
\hline Compliance with Six Sigma performance & Lack of long-term quality vision and strategy \\
\hline $\begin{array}{l}\text { Bidirectional connection of people } \\
\text { and processes }\end{array}$ & $\begin{array}{c}\text { Top manager mental stereotypes and } \\
\text { unwillingness }\end{array}$ \\
\hline Possible mass customization of production & $\begin{array}{l}\text { Significant time and capital resources, } \\
\text { including investment }\end{array}$ \\
\hline $\begin{array}{l}\text { Enforcing quality assurance across the product } \\
\text { value chain }\end{array}$ & $\begin{array}{l}\text { Intensive IT support and close cooperation } \\
\text { with IT specialists }\end{array}$ \\
\hline Possibility of rapid quality interventions & Radical organisational innovations \\
\hline More accurate customer voicing & \\
\hline
\end{tabular}

These findings are valid also for the automotive industry, which represents an impressive strength of Czech economy: its share in Gross Domestic Product is about 9.0\%, and automotive share in total industrial production is 23\% [77]. Massive robotics and digitalisation of the main processes there are accompanied mostly by traditional quality management methods and approaches. These opinions strongly correlate with the results presented by Horváth and Szabo [78].

Although technology and hardware issues are usually a matter of priority in academic discussions and research work, we must not afford to ignore the soft and social issues always associated with human resources development, including proper communication between all people and stakeholders. According to Aldag and Eker [79], this is a key to a successful implementation of Quality 4.0 concept. Therefore, further development of closed-loop quality management systems according to the model illustrated in Figure 2 or Table 1 can contribute to the comprehensive and efficient communication with all stakeholders. It is obvious that the investigations focused on human factors of Quality 4.0 concept have so far been a little bit underestimated. In addition, all the features of mutual relationship between customer loyalty and corporate sustainable also represent impressive tasks for future research.

Efforts in the field of Quality 4.0 are taking place all over the world, as well as development of closed-loop quality management systems. Their impacts on sustainability are currently only estimated, and all statements should be considered as assumptions waiting for confirmation.

Summarising all findings and lessons learned (derived from a literature review as well as from personal experience), further research challenges should cover the following areas of interest:

(a) Overall development of closed-loop quality management systems must continue with special regard to involving all stakeholders. The last version of The EFQM Model [73] can serve as a commonly accepted tool.

(b) Further development of loyalty monitoring and measurement should involve all stakeholders, including employees, suppliers, etc. 
(c) The impacts of increasing stakeholder loyalty on the organisations' sustainability changes should be also investigated.

(d) Risks and opportunities related to digital internal and external communication regarding to social impacts also wait for serious research (especially in COVID-19 pandemic situation).

(e) All loops presented in Table 1 earlier should be filled with detailed types of information flows required by different international standards, excellence or sustainability models, etc.

(f) Finally, what is a fundamental, the clear and commonly accepted vocabulary related to Quality 4.0 should be developed as soon as possible.

Author Contributions: Conceptualization, J.N. and D.V.; methodology, J.N. and D.V.; validation, J.N., D.V. and E.T.; formal analysis, J.N., D.V. and E.T.; investigation, J.N., D.V. and E.T.; resources, J.N., D.V. and E.T.; data curation, J.N., D.V. and E.T.; writing—original draft preparation, J.N., D.V. and E.T.; writing-review and editing, J.N., D.V. and E.T.; visualization, D.V.; supervision, J.N. All authors have read and agreed to the published version of the manuscript.

Funding: This work was supported by the European Regional Development Fund under a grant "A Research Platform Focused on Industry 4.0 and Robotics in the Ostrava Agglomeration" project, no. CZ.02.1.01/0.0/0.0/17_049/000845 and VŠB-Technical University of Ostrava. This research was funded by the specific research project "USE OF SELECTED APPROACHES, METHODS AND TOOLS OF QUALITY MANAGEMENT IN THE CONTEXT OF THE DEVELOPMENT OF THE CONCEPT OF QUALITY 4.0," SP2021/54, which has been solved at the Faculty of Materials Science and Technology, VŠB-Technical University of Ostrava with the support of Ministry of Education, Youth and Sports, Czech Republic.

Institutional Review Board Statement: Not applicable.

Informed Consent Statement: Informed consent was obtained from all subjects involved in the study.

Data Availability Statement: Not applicable.

Acknowledgments: We are thankful for active participation to all Czech organisations, which gave us valuable response during field research aimed to investigation how complex customer loyalty measurement is understood and implemented.

Conflicts of Interest: The authors declare no conflict of interest.

\section{References}

1. Jacob. D. Quality 4.0 Impact and Strategy Handbook; LNS Research: Cambridge, UK, 2017.

2. Industry 4.0 Engages Customers; Deloitte University Press: Westlake, TX, USA; Available online: www2.deloitte.com (accessed on 12 November 2020).

3. Kupper, D.; Knizek, C.; Ryeson, D. Quality 4.0 Takes More Than Technology. Available online: Bcg.com/publications/2019 / quality-4.0-takes-more-than-technology (accessed on 4 February 2020).

4. Chiarini, A. Industry 4.0, quality management and TQM world. A Systematic literature review and proposed agenda for further research. TQM J. 2020, 32, 13. [CrossRef]

5. Lim, J.S. Quality Management in Engineering-A Scientific and Systematic Approach; CRC Press: Boca Raton, FL, USA, 2020.

6. Zonnenshain, A.; Kenett, R.S. Quality 4.0-The challenging future of quality engineering. Qual. Eng. 2020, 32, 12. [CrossRef]

7. Antony, J. Quality 4.0: Enhancing Organisations' Quality Management Practices to the Next Level. Available online: www. thefuturefactory.com/blog/48 (accessed on 4 November 2020).

8. Zimon, D.; Madzik, P.; Sroufe, R. Management systems and improving supply chain processes. Int. J. Retail Distrib. Manag. 2019, 48, 22. [CrossRef]

9. Oakland, J.S.; Oakland, R.J.; Turner, M.A. Total Quality Management and Operational Excellence-Text with Cases, 5th ed.; Routledge: London, UK, 2020.

10. Sreedharan, R.; Raju, R.; Srinivas, S. A review of the quality evolution in various organizations. Total Qual. Manag. Bus. Excell. 2017, 28, 351-365. [CrossRef]

11. Ching-Chow, Y. The Evolution of Quality Concepts and Related Quality Management. In Quality Control and Assurance-An Ancient Greek Term Re-Mastered; IntechOpen: London, UK, 2017. [CrossRef]

12. Radziwill, N. The Future of Quality Is Revolutionary. 2014. Available online: https:/ / qualityandinnovation.com (accessed on 21 May 2019). 
13. McGrath, R.G. Management's Three Eras: A Brief History. 2014. Available online: https://hbr.org/2014/07 (accessed on 16 June 2019).

14. Sundaram, K. Quality in the Future of Manufacturing; Frost and Sullivan: Santa Clara, CA, USA, 2018.

15. Cattaneo, L.; Rossi, M.; Negri, E.; Powell, D.; Terzi, S. Lean Thinking in the Digital Era. In Product Lifecycle Management and the Industry of the Future, Proceedings of the PLM 2017-IFIP Advances in Information and Communication Technology; Ríos, J., Bernard, A., Bouras, A., Foufou, S., Eds.; Springer: Cham, Switzerland, 2017; Volume 517. [CrossRef]

16. Ponsignon, F.; Kleinhans, S.; Bressolles, G. The contribution of quality management to an organisation's digital transformation: A qualitative study. Total Qual. Manag. Bus. Excell. 2019. [CrossRef]

17. Littlefield, M. Closed-Loop Quality Management: What You Need to Know about It. 2014. Available online: www.ibaset.com/ blog/closed-loop-quality-management (accessed on 12 December 2018).

18. Research Spotlight. Closed-Loop Quality: Connecting Engineering, Manufacturing and Quality. Available online: www. Insresearch.com (accessed on 14 December 2018).

19. van der Laan, E.A. Closed Loop Supply Chain Management. In Operations, Logistics and Supply Chain Management-Lecture Notes in Logistics; Zijm, H., Klumpp, M., Regattieri, A., Heragu, S., Eds.; Springer: Cham, Switzerland, 2019. [CrossRef]

20. Nikolaidis, Y. Quality Management in Reverse Logistics; Springer: London, UK, 2013.

21. Almaraj, I.I.; Trafalis, T.B. An integrated multi-echelon robust closed-loop supply chain under imperfect quality production. Int. J. Prod. Econ. 2019, 218, 212-227. [CrossRef]

22. Goulévitch, V. Eight Examples of Properly Working Closed-Loop Quality System. 2018. Available online: www.controleng.com/ articles (accessed on 13 November 2018).

23. Littlefield, M.; Shah, M. Closed Loop Quality Management. Improving Customer Focus from Design to Delivery. 2009. Available online: www.apriso.com (accessed on 4 May 2018).

24. Sony, M.; Antony, J.; Douglas, J.A. Essential ingredients for the implementation of Quality 4.0. A narrative review of literature and future directions for research. TQM J. 2020, 32, 14. [CrossRef]

25. Foidl, H.; Felderer, M. Research Challenges of Industry 4.0 for Quality Management. ERP Future; Springer: Cham, Switzerland, 2016. [CrossRef]

26. Sisodia, R.; Forero, D.V. Quality 4.0 How to Handle Quality in the Industry 4.0 Revolution. Master Thesis, Chalmers University of Technology, Gothenburg, Sweden, 2020.

27. Hayes, B. Measuring Customer Satisfaction and Loyalty, 3rd ed.; ASQ Quality Press: Milwaukee, WI, USA, 2008.

28. Watson, G.F.; Beck, J.T.; Henderson, C.M.; Palmentier, R.W. Building, measuring, and profiting from customer loyalty. J. Acad. Mark. Sci. 2015, 43, 790-825. [CrossRef]

29. Reichheld, F. The Loyalty Effect: The Hidden Force Behind Growth, Profit and Lasting Value; Harvard Business School Press: Boston, MA, USA, 1996.

30. Martensen, A.; Gronholdt, L.; Kristensen, K. The drivers of customer satisfaction and customer loyalty: Cross-industry findings from Denmark. Total Qual. Manag. 2000, 11, 544-553. [CrossRef]

31. Bowen, J.T.; Shiang-Lih, C. The relationship between customer loyalty and customer satisfaction. Int. J. Contemp. Hosp. Manag. 2000, 13, 213-217. [CrossRef]

32. Kumar, V.; Shah, D. Building and sustaining profitable customer loyalty for 21st century. J. Retail. 2001, 80, 317-329. [CrossRef]

33. Hayes, B. Lessons in Loyalty. Qual. Progress 2011, 44, 24-31.

34. Garfield, B.; Levy, D. Can't Buy Me Like-How Authentic Customer Connections Drive Superior Results; Penguin Group: London, UK, 2013.

35. Hill, N.; Alexander, J. The Handbook of Customer Satisfaction and Loyalty Measurement, 3rd ed.; Routledge: New York, NY, USA, 2017.

36. Nenadál, J. Měření v Systémech Managementu Jakosti; Management Press: Prague, Czech Republic, 2001.

37. Rauyruen, P.; Miller, K.E. Relationship quality as a predictor of B2B customer loyalty. J. Bus. Res. 2007, 60, 21-31. [CrossRef]

38. Baumann, C.H.; Hoadley, S.; Hamin, H.; Nugraha, A. Competitiveness vis-à-vis service quality as drivers of customer loyalty mediated by perceptions of regulation and stability in steady and volatile markets. J. Retail. Consum. Serv. 2017, 36, 62-74. [CrossRef]

39. Troebs, C.; Wagner, T.; Heidemann, F. Transformative retail services: Elevating loyalty through customer well-being. J. Retail. Consum. Serv. 2018, 45, 198-206. [CrossRef]

40. Liu, M.T.; Liu, Y.; Mo, Z.; Zhao, Z.; Zhu, Z. How CSR influences customer behavioural loyalty in the Chinese hotel industry. Asia Pac. J. Mark. Logist. 2019, 32, 1-22. [CrossRef]

41. $\mathrm{Xu}, \mathrm{X} . ; \mathrm{Jackson}$, J.E. Investigating the influential factors of return channel loyalty in omni-channel retailing. Int. J. Prod. Econ. 2019, 216, 118-132. [CrossRef]

42. Reinartz, W.; Kumar, V. The Mismanagement of Customer Loyalty_Increasing Customer Loyalty; Harvard Business Review Press: Boston, MA, USA, 2011.

43. Hayes, B. Beyond the Ultimate Question-A Systematic Approach to Improve Customer Loyalty; ASQ Quality Press: Milwaukee, MI, USA, 2009.

44. Skačkauskiené, I.; Vilkaité-Vaitoné, N.; Vojtovic, S. Model for measuring customer loyalty towards a service provider. J. Bus. Econ. Manag. 2015, 16, 1185-1200. [CrossRef] 
45. Zena, P.A.; Hadisumato, A.D. The Study of Relationship among Experiental Marketing, Service Quality, Customer Satisfaction and Customer Loyalty. ASEAN Mark. J. 2013, 4, 1-10. [CrossRef]

46. Tanford, S.; Raab, C.; Kim, Y.S. Determinants of customer loyalty and purchasing behaviour for full-service and limited-service hotels. Int. J. Hosp. Manag. 2012, 31, 319-328. [CrossRef]

47. Bardauskaite, I. Loyalty in the Business-to-Business Service Context: A Literature review and Proposed Framework. J. Relatsh. Mark. 2014, 13, 28-69. [CrossRef]

48. Askariazad, M.H.; Babakhani, N. An application of European Customer Satisfaction Index (ECSI) in business to business (B2B) context. J. Bus. Ind. Mark. 2015, 30, 17-31. [CrossRef]

49. Russo, I.; Confents, I.; Gligor, D.M.; Autry, C.W. To be or not to be (loyal): Is there a recipe for customet loyalty in the B2B context? J. Bus. Res. 2016, 69, 888-896. [CrossRef]

50. Youssef, Y.M.A.; Johnston, W.J.; Abdelhamid, T.A.; Dakrory, M.I.; Seddick, M.G.S. A customer engagement framework for B2B context. J. Bus. Ind. Mark. 2018, 33, 145-152. [CrossRef]

51. International Organization for Standardization 9001:2015. Quality Management System—Requirements; ISO: Geneva, Switzerland, 2015.

52. International Organization for Standardization 9004:2018. Quality Management_Quality of an Organization-Guidance to Achieve Sustained Success; ISO: Geneva, Switzerland, 2018.

53. Abu-Alhaija, A.S.; Yusof, R.N.R.; Hashim, H.; Jaharuddin, N.S. Determinants of Customer Loyalty: A Review and Future Directions. Australian J. Basic Appl. Sci. 2018, 12, 106-111. [CrossRef]

54. Siva, V.; Gremyr, I.; Halldórsson, A. Organising Sustainability Competencies through Quality Management: Integration or Specialisation. Sustainability 2018, 10, 1326. [CrossRef]

55. Nguyen, M.H.; Phan, A.C.; Matsui, Y. Contribution of Quality Management Practices to Sustainability Performance of Vietnamese Firms. Sustainability 2018, 10, 375. [CrossRef]

56. Veldwijk, J. The Role of Sustainbility in Customer Loyalty. Available online: https://customerthink.com (accessed on 24 October 2020).

57. Garai, T. Go Green, Get Green: Sustainability in Loyalty Programs. Available online: https://antavo.com/blog/sustainabilityloyalty-programs (accessed on 6 November 2020).

58. Weinberg, J. Sustainability and Customer Loyalty. Available online: www.linkedin.com/pulse/sustainability-customer-loyaltyjay-weinberg (accessed on 17 November 2020).

59. Siva, V.; Gremyr, I.; Berquist, B.; Garvare, R.; Zubel, T.; Isaksson, R. The support of Quality Management to sustainable development: A literature review. J. Clean. Prod. 2016. [CrossRef]

60. Vila-Brunet, N.; Llach, J. OSS-Qual: Holistic Scale to Assess Customer Quality Perception When Buying Secondhand Products in Online Platforms. Sustainability 2020, 12, 9256. [CrossRef]

61. Strenitzerová, M.; Gaňa, J. Customer Satisfaction and Loyalty as a Part of Customer-Based Corporate Sustainability in the Sector of Mobile Communications Services. Sustainability 2018, 10, 1657. [CrossRef]

62. Investopedia. Dow Jones STOXX Sustainability Index. Available online: www.investopedia.com/terms/d/djones-stoxxsustainability.asp (accessed on 7 November 2018).

63. International Organization for Standardization 26000. Guidance on Social Responsibility; ISO: Geneva, Switzerland, 2010.

64. Dapi, B.; Phiri, M. The impact of corporate social responsibility on brand loyalty. J. Gov. Regul. 2015, 4. [CrossRef]

65. Mandhachitara, R.; Poolthong, Y. A model of customer loyalty and corporate social responsibility. J. Serv. Mark. 2011, 25. [CrossRef]

66. Cuesta-Valino, P.; Rodriguez, P.G.; Bariopedro, E.N. The impact of corporate social responsibility on customer loyalty in hypermarkets: A new socially responsible strategy. Corp. Soc. Responsib. Environ. Manag. 2019, 26, 761-769. [CrossRef]

67. Moisescu, O. From perceptual corporate sustainability to customer loyalty: A multi-sectorial investigation in a developing country. Econ. Res.-Ekon. Istraživanja. 2018, 31, 55-72. [CrossRef]

68. Sader, S.; Husti, I.; Daróczi, M. Industry 4.0 as a Key Enabler toward Successful Implementation of Total Quality Management Practices. Period. Polytech. Soc. Manag. Sci. 2019, 27, 9. [CrossRef]

69. Goeks, L.S.; dos Santos, A.A.; Korzenowski, A.L. Decision-making trends in quality management: A literature review about Industry 4.0. Production 2020, 30. [CrossRef]

70. Vykydal, D.; Halfarová, P.; Nenadál, J. Customer Loyalty Measurements at Czech Organizations. Qual. Innov. Prosper. 2013, 17, 11. [CrossRef]

71. Tylečková, E. Rozvoj Přístupů k Měření Komplexní Loajality Zákazníků v Průmyslových Organizacích. Master Thesis, VSBTechnical University of Ostrava, Ostrava, Czech Republic, 2019.

72. Tague, N.R. Quality Toolbox, 2nd ed.; Cengage Learning: Boston, MA, USA, 2015.

73. The EFQM Model; European Foundation for Quality Management: Brussels, Belgium, 2019.

74. Nenadál, J. The New EFQM Model: What is Really New and Could Be Considered as a Suitable Tool with Respect to Quality 4.0 Concept? Qual. Innov. Prosper. 2020, 24, 12. [CrossRef]

75. Kiran, D.R. Total Quality Management, 1st ed.; Butterworth-Heinemann: Oxford, UK, 2016.

76. Krubasik, S. Quality 4.0: Preventive, Holistic, Future-Proof. Available online: www.atkearney.com (accessed on 21 December 2019). 
77. Autosap. Základní Přehledy Automotive. Available online: https://autosap.cz/zakladni-prehledy-automotive/ (accessed on 15 August 2020).

78. Horváth, D.; Szabó, Z. Driving forces and barriers of Industry 4.0: Do multinational and small and medium-sized companies have equal opportunities? Technol. Forecast. Soc. Chang. 2019, 146, 119-132. [CrossRef]

79. Aldag, M.C.; Eker, B. What is Quality 4.0 in the Era of Industry 4.0? Available online: https://researchgate.net/publication/3294 42755_WHAT_IS_QUALITY_40_IN_THE_ERA_OFINDUSTRY_40 (accessed on 21 April 2020). 